\title{
MENGUKUR EFEKTIFITAS PROSES PEMBELAJARAN DISCOVERY LEARNING PADA POKOK BAHASAN USAHA DAN ENERGI
}

\author{
Ade Putri ${ }^{1}$ \\ ${ }^{1}$ Program Studi Pendidikan Fisika, Fakultas Tarbiyah dan Keguruan, UIN Sunan Gunung Djari \\ Bandung, Indonesia \\ E-mail: adelp7980@gmail.com
}

\begin{abstract}
ABSTRAK
Pembelajaran fisika di SMK dirasa belum efektif, hal ini dikarenakan minimnya media dan bahan ajar selama kegiatan pembelajaran berlangsung, selain itu kemampuan guru dalam menggunakan metode dan model yang sama, mengakibatkan pembelajaran dikelas menjadi monoton dan berdampak pada rendahnya pengetahuan dan keterampilan peserta didik. Tujuan dalam penelitian ini yaitu mengukur efektifitas pembelajaran dengan model Discovery Learning pada materi usaha dan energi melalui sistem penilaian AABTLT with SAS. Metode penelitian yang digunakan adalah metode deskriptif. Penelitian di lakukan di SMK Muhammadiyah 2 Cibiru, dengan sampel penelitian adalah peserta didik dari kelas X RPL yang berjumlah 41 orang. Hasil penelitian menunjukan bahwa adanya hubungan antara rancangan pembelajaran yang telah disiapkan dengan ketercapaian pembelajaran oleh peserta didik. Penelitian ini menyimpulkan bahwa penggunaan model Discovery Learning dapat mengukur efektifitas pembelajaran yang dilihat melalui rata-rata capaian pembelajaran tiap langkah kegiatan melebihi 50\%, di mana pada kegiatan pendahuluan mencapai 82,14\%, kegiatan inti 71,83\% dan kegiatan penutup 61,31\%.
\end{abstract}

Kata kunci: discovery learning, AABTLT with SAS

\begin{abstract}
Physics learning in Vocational High School is considered ineffective, this is due to the lack of media and teaching materials during the learning activities. In addition, the ability of teachers to use the same methods and models, asking for learning in the classroom becomes monotonous and increases the knowledge and skills of students. The purpose of this research is to measure the effectiveness of learning with the Discovery Learning model on work and energy material through the AABTLT with SAS assessment system. The method used is descriptive method. The research was conducted at the Muhammadiyah 2 Cibiru Vocational School, with the sample of the study being 41 students from class X RPL. The results of the study show that there is a relationship between learning design that has been prepared with the achievement of learning by students. This research concludes that the use of the Discovery Learning model can measure the effectiveness of learning which shows the average achievement of each step of the activity exceeds $50 \%$, where in the preliminary activities reached $82.14 \%$, essences activities $71.83 \%$ and closing activities $61.31 \%$ Keywords: discovery learning, AABTLT with SAS
\end{abstract}

DOI: http://dx.doi.org/10.15575/jtlp.v2i1.6588

Received: 12 Desember 2016 ; Accepted: 14 Februari 2017; Published: 1 Maret 2017 


\section{PENDAHULUAN}

Pendidikan merupakan kebutuhan dasar yang harus dilakukan oleh manusia, karena dengan pendidikan, seseorang dapat mengembangkan setiap potensi yang ada dalam diri mereka sendiri. Pendidikan juga dapat diartikan sebagai rangkaian proses dalam mendapatkan pengetahuan, perilaku yang sesuai dan keterampilan (Martaida, Bukit, \& Ginting, 2017). Pendidikan yang bermutu dihasilkan dari sumber daya manusia yang bermutu pula. Untuk melahirkan sumber daya manusia yang bermutu hendaknya seseorang yang berkecimpung di dalam dunia pendidikan adalah orang yang berkompeten (Hermawan, 2014). Kompetensi guru yang perlu dikuasai dalam memenej pembelajaran di sekolah salah satunya adalah kompetensi pedagogik (Mirzagitova \& Akhmetov, 2015); (Rochman, 2015). Melalui kompetensi pedagogik yang dimilikinya, seorang guru dapat merancang kegiatan pembelajaran dengan baik, mulai dari penerapan strategi, metode dan model pembelajaran selama pembelajaran berlangsung (Eka Andriani, Sumarmi, 2016).

Fisika merupakan ilmu alam yang berperan penting terhadap kemajuan pendidikan di Indonesia. Selain itu, fisika berperan penting dalam kemajuan sains dan teknologi (Wingrave et al., 2012) (Helliar \& Harrison, 2011). Dalam konteks kemajuan dunia sains dan teknologi, pembelajaran fisika hendaknya dapat menuntut siswa untuk berpikir kritis, mengkontruksi pengetahuan, menemukan konsep dan menyelesaikan setiap permasalahan berdasarkan pengetahuan yang dimilikinya (Balım, 2009); (Joy, 2014). Berdasarkan Permendiknas Nomor 22 tahun 2006 bahwa pada tingkat SMA/SMK/MA, Fisika penting untuk diajarkan sebagai mata pelajaran tersendiri dengan beberapa pertimbangan. Pertama, pembelajaran fisika merupakan suatu wahana untuk menumbuhkan kemampuan berpikir kritis yang berguna untuk memecahkan segala permasalahan yang terjadi dalam kehidupan sehari-hari. Kedua, melalui pembelajaran fisika, peserta didik dibekali pengetahuan, pemahaman untuk berbagai kemampuan yang dipersyaratkan untuk memasuki jenjang yang lebih tinggi, sehingga dapat mengembangkan ilmu dan teknologi (Sijaya, Yani, \& Ma'ruf, 2015).

Akan tetapi, masih banyak peserta didik yang tidak menyukai mata pelajaran fisika, hal ini dikarenakan anggapan mereka bahwa mata pelajaran fisika merupakan mata pelajaran tersulit dibandingkan dengan mata pelajaran lainnya (Nasrudin, 2012). Alasan lain mengapa mereka tidak menyukai mata pelajaran ini adalah ketidakpahaman terhadap penjelasan dari guru, hal ini bisa terjadi karena penggunaan metode dan model pembelajaran yang tidak tepat (Kapucu, 2016). Penelitian menujukkan bahwa selain kemampuan pedagogik guru, faktor yang menjadi pemicu banyaknya peserta didik yang tidak menyukai fisika adalah pemberian contoh yang kurang konkrit, dan ketidaktahuan makna dari persamaan matematika yang mereka pelajari (Wingrave et al., 2012). Faktor-faktor inilah yang nantinya akan berpengaruh terhadap rendahnya penguasaan konsep peserta didik terhadap pembelajaran yang mereka lakukan.

Menurut (Hidayat, Lesmanawati, \& Maknun, 2014) dalam (Aksit, Niemi, \& Nevgi, 2016) bahwa faktor penentu keberhasilan proses pembelajaran adalah aktivitas peserta didik itu sendiri, di mana dalam proses pembelajaran peserta didik dituntut untuk aktif dan tanggap dalam menyelesaikan setiap permasalahan yang diberikan oleh guru. Hal itu tidak akan tercapai, jika peserta didiknya sendiri tidak memiliki motifasi dalam belajar. Selain peserta didik, faktor penentu keberhasilan pembelajaran lainnya adalah cara guru dalam mengolah pembelajaran meliputi penerapan metode, 
strategi, pendekatan dan model pembelajaran (Ismail, 2010), (Mupa \& Chinooneka, 2015).

Upaya yang dapat dilakukan agar tercapainya proses pembelajaran yang efektif salah satunya dengan menggunakan model discovery learning. Model discovery learning adalah model yang berisi serangkaian kegiatan pembelajaran dengan menekankan proses berpikir kritis dan analisis untuk mencapai dan menemukan jawaban mereka sendiri terhadap masalah yang disajikan (Martaida et al., 2017). Pada pembelajaran menggunakan model discovery learning, peserta didik menjawab dan menyelesaikan permasalahan yang disajikan di bawah bimbingan guru (Pangaribowo, Keliat, Sastrodihardjo, \& Hutangoal, 2017). Model discovery learning memungkinkan peserta didik untuk menggunakan seluruh pengetahuan (kognitif, afektif dan psikomotorik), dalam proses belajar untuk menemukan konsep atau prinsip sendiri.

Keuntungan diterapkannya model pembelajaran discovery learning adalah meningkatan level pengetahuan peserta didik (Suphi \& Yaratan, 2016). Selain itu, dengan menggunakan model discovery learning, peserta didik dapat mengkonstruksikan pengetahuan sendiri, kemudian mentransfer pengetahuan yang dimilikinya kepada rekannya dalam memecahkan permasalahan yang ada (Cohen, 2008). Keuntungan lain yang didapatkan ketika menggunakan model discovery learning adalah meningkatnya keterampilan berpikir kritis (Martaida et al., 2017 dan keterampilan proses sains peserta didik (Khabibah, Masykuri, \& Maridi, 2017) beberapa keuntungan inilah yang nantinya akan menjadikan pembelajaran menjadi lebih efektif.

Pembelajaran yang efektif dapat terlihat melalui penilaian hasil belajar peserta didik. Dalam hal ini, penilaian yang dilakukan mengacu pada langkah kegiatan pembelajaran yang ada dalam sintak model discovery learning dan sistem penilaian Authentic Assesment Based on Teaching and Learning Trajectory (AABTLT) with Student Activity Sheet (SAS). Di mana kegiatan pembelajaran direkam menggunakan alat berupa SAS (Student Activities Sheet). Berdasarkan hal tersebut, maka tujuan penelitian ini adalah untuk Mengukur Efektifitas Pembelajaran dengan Model Discovery Learning menggunakan sistem penilaian Authentic Assesment Based on Teaching and Learning Trajectory (AABTLT) with Student Activity Sheet (SAS).

\section{METODE PENELITIAN}

Metode yang digunakan dalam penelitian ini adalah metode deskriptif, yaitu suatu metode untuk mendeskripsikan gejala, fenomena serta kejadian baik yang sudah berlangsung ataupun sedang berlangsung. Penelitian ini dilakukan di SMK Muhammadiyah 2 Cibiru dengan sampel siswa kelas X RPL yang berjumlah 41 orang dengan menggunakan teknik random sampling. Random sampling atau pengambilan sampel secara acak, di mana setiap individu dalam populasi mempunyai peluang yang sama untuk dijadikan sampel. Instrumen yang digunakan berupa tes uraian yang terdiri dari 7 soal, yang mengacu pada langkah pembelajaran melalui sintaks model pembelajaran discovery learning pada materi usaha dan energi. Data penelitian diperoleh melalui sistem penilaian Authentic Assesment Based on Teaching and Learning Trajectory (AABTLT) with Student Activity Sheet (SAS) dalam merekam proses pembelajaran peserta didik melalui model Discovery Learning. Dalam rangkaian proses pembelajaran, terdapat salah satu aspek penting, yaitu penilaian. Penilaian yang dilakukan hendaknya bersifat autentik. Penilaian autentik merupakan ukuran pencapaian tingkat intelektual peserta didik yang efektif, karena peserta didik di minta untuk 
menunjukkan pemahaman mendalam mereka, kemampuan berpikir tingkat tinggi, dan pemecahan masalah yang kompleks melalui kinerja tugas-tugas yang diberikan

Penilaian hasil belajar sebagai langkah untuk melihat tingkat keberhasilan proses pembelajaran yang telah dilakukan. Pembelajaran yang berkualitas dan bermakna mampu meningkatkan kemampuan/kompetensi dan hasil belajar peserta didik, sehingga aspek hasil belajar peserta didik menjadi tolok ukur keberhasilan proses pembelajaran (Hamid, 2016). Selain itu, penilaian hasil pembelajaran juga berpengaruh terhadap efektifitas pembelajaran (Rosdiana., Boleng, \& Susilo., 2017). Penilaian hasil belajar yang dilakukan adalah dengan merekam proses pembelajaran dari awal hingga akhir melalui alat yang disebut SAS (Student Activity Sheet), di mana dalam SAS ini merupakan lembar jawaban peserta didik terhadap permasalahan yang disajikan oleh guru. Data utama yang menjadi data penelitian adalah SAS dari peserta didik. SAS inilah yang akan diperiksa kemudian diberikan skor sesuai rubrik yang telah ditentukan. Rubrik penilaian dari setiap jawaban peserta didik dibuat dalam skala 0-4 dengan penjelasan seperti tabel berikut ini

Table 1 Rubrik Penilaian AABTLT withs SAS

\begin{tabular}{cc}
\hline Skor & Kriteria \\
\hline 4 & Jika sesuai jawaban yang sempurna \\
& $\begin{array}{c}\text { Jika jawaban yang diberikan benar dan } \\
\text { lengkap tetapi belum sempurna seperti } \\
\text { yang diharapkan }\end{array}$ \\
2 & Jika jawaban benar namun tidak lengkap \\
Kkiteria \\
1 & Jika responden memberikan jawaban \\
0 & yang salah \\
& Jika responden tidak memberi jawaban \\
\hline
\end{tabular}

Selanjutnya, SAS yang sudah diberi skor dan diakumulasi untuk setiap responden akan diolah dan dianalisis menggunakan statistik deskriptif dan dinyatakan dalam persentase capaian pembelajaran. Adapun kriteria rata-rata capaian pembelajaran dari peserta didik diberikan pada tabel 2 berikut.

Tabel 2 Rata-rata Efektifitas Pembelajaran

\begin{tabular}{|c|c|c|}
\hline $\begin{array}{c}\text { Persentase } \\
\text { Rata-rata } \\
\text { Capaian } \\
\text { Pembelajaran }\end{array}$ & $\begin{array}{c}\text { Rata-Rata } \\
\text { Capaian } \\
\text { Pembelajaran }\end{array}$ & Kriteria \\
\hline$<55$ & $2.1-0$ & $\begin{array}{l}\text { Kurang } \\
\text { Efektif }\end{array}$ \\
\hline $56-70$ & $2.2-2.7$ & $\begin{array}{l}\text { Cukup } \\
\text { Efektif }\end{array}$ \\
\hline $71-85$ & $2.8-3.4$ & \begin{tabular}{l} 
Efektif \\
\hline $86-100$
\end{tabular} \\
\hline
\end{tabular}

\section{HASIL DAN PEMBAHASAN}

\section{a. Rata-Rata Capaian Perkuis}

Capaian hasil pembelajaran yang dilakukan pada bahasan Usaha dan energi dilakukan melalui pemberian soal uraian yang terdiri dari 7 butir soal kuis. Di mana masing-masing soal sesuai dengan langkah pembelajaran, yaitu kegiatan inti direkam melalui (Q1 dan Q2), kegiatan inti (Q3, Q4, Q5) dan kegiatan penutup (Q6 dan Q7). Adapun untuk rata-rata capaian hasil pembelajaran perkuis dapat dilihat pada grafik 1 .

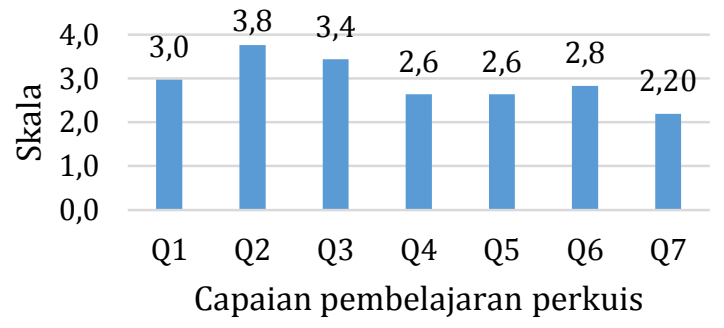

Grafik 1 Ketercapaian Pembelajaran Perkuis

Berdasarkan grafik tersebut, rata-rata capaian setiap kuis bervariasi, rata-rata tertinggi ditunjukan pada Q2 yaitu 3,8 dan Q3 yaitu 2,20, hal ini karena Q2 dilaksanakan diawal pembelajaran, peserta didik masih semangat dan fokus dalam mengikuti kegiatan pembelajaran, sedangkan Q3 berada pada kegiatan inti awal di 
mana peserta didik diberikan suatu stimulus terlebih dahulu mengenai konsep usaha dan energi dalam kehidupan nyata, sehingga ketika diberikan soal mengenai konsep usaha dan energi, peserta didik menjadi lebih paham. Adapun rata-rata kuis terendah ada pada Q7, hal ini dikarenakan suasana kelas yang sudah tidak kondusif dikarenakan mata pelajaran fisika berada pada jam terakhir, sehingga pada quis 7 ini banyak dari peserta didik yang sudah tidak fokus dalam belajar akibatnya berdampak pada capaian hasil pembelajaran kegiatan penutup yang diukur melalui Q7.

\section{b. Rata-Rata Capaian Hasil Belajar Peserta Didik}

Rata-rata capaian hasil pembelajaran peserta didik terhadap 7 butir kuis yang disajikan dapat dilihat melalui grafik berikut:

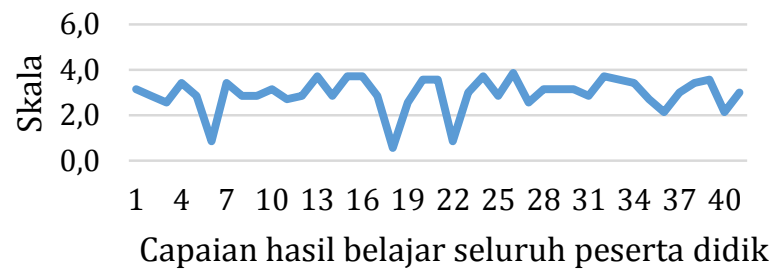

Grafik 2 Rata-rata Capaian Hasil Belajar Peserta Didik

Berdasarkan grafik di atas, capaian hasil pembelajaran peserta didik bervariasi, rata-rata capaian hasil pembelajaran peserta didik tertinggi ada pada skala 3,9. Dan terendahnya ada pada skala 0,6. Dilihat dari grafik tersebut ratarata capaian hasil belajar peserta didik sudah dapat menggambarkan keefektifan pembelajaran, walaupun ada sebagian kecil yang mendapatkan capaian hasil pembelajaran yang kecil sekitar $12 \%$ dari total keseluruhan, akan tetapi pembelajaran masih dikategorikan menjadi pembelajaran yang efektif.

\section{c. Ketercapaian Perkegiatan}

Kegiatan pembelajaran yang dilakukan terdiri dari kegiatan pendahuluan, kegiatan inti dan kegiatan penutup. Kegiatan pendahuluan dilakukan dengan memberikan suatu stimulus kepada peserta didik yaitu melakukan demosntrasi sederhana terkait usaha dan energi, kemudian memberikan 2 pertanyaan terkait demonstrasi yang dilakukan. Pada kegiatan inti, guru menjelaskan terkait materi yang disajikan dan melakukan beberapa percobaan agar peserta didik lebih mudah memahami penjelasan guru, kemudian pada akhir kegiatan inti, peserta didik diberikan 3 buah permasalahan terkait penjelasan materi untuk kemudian mengintruksikan peserta didik bekerja sama dengan teman kelompoknya dalam melakukan menemukan dan memecahkan permasalahan yang diberikan guru dibawah bimbingan guru. Adapun pada kegiatan penutup, guru melakukan refleksi terhadap pembelajaran dengan memberikan 2 pertanyaan terkait kegiatan pembelajaran yang telah dilaksanakan dari kegiatan pendahuluan hingga kegiatan inti. Adapun rata-rata dari capaian perkegiatan tersebut dapat digambarkan pada grafik 3 .

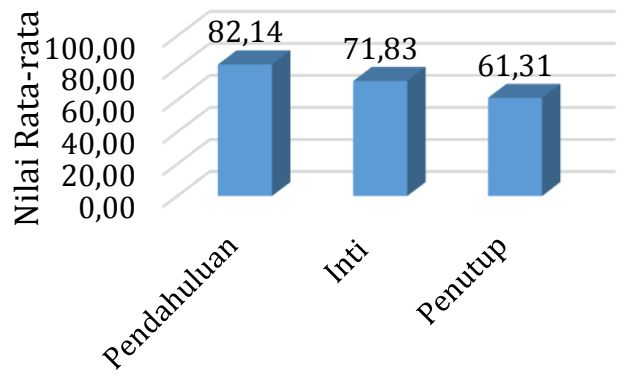

Kegiatan Pembelajaran

Grafik 3 Rata-rata Ketercapaian Perkegiatan

Berdasarkan grafik 3, rata-rata ketercapaian perkegiatan untuk kegiatan pendahuluan yaitu sekitar 82,14 \%, kegiatan inti sekitar 71,83\% dan kegiatan penutup sekitar 61,31\%. Berdasarkan tabel 2 proses pembelajaran yang efektif ada pada kegiatan pendahuluan dan inti, sedangkan pada kegiatan penutup kurang efektif, hal ini dikarenakan pembelajaran di kelas sudah tidak 
kondusif, dan banyak dari peserta didik yang terganggu konsentrasinya melihat teman kelas yang lain sudah terlebih dahulu keluar.

Berdasarkan grafik 3 jika ditinjau dari kegiatan inti, pembelajaran sudah dikatakan efektif, karena pada saat kegiatan inti terdapat interaksi antara peserta didik dengan rekan kelompoknya dan antara peserta didik dengan guru, sehingga menghasilkan capaian hasil pembelajaran yang tinggi dibandingkan dengan kegiatan lainnya.

\section{SIMPULAN}

Berdasarkan penelitian yang dilakukan, didapatkan bahwa penggunaan model discovery learning pada pembelajaran fisika di SMK Muhammadiyah 2 Cibiru dengan sistem penilaian AABTLT with SAS dapat mengukur efektifitas pembelajaran. Hal ini dapat dilihat dari capaian rata-rata hasil pembelajaran perkegiatan yang mencapai lebih dari 50\%, di mana pada kegiatan pendahuluan tercapai sekitar 82,14\%, kegiatan inti $71,83 \%$ dan kegiatan penutup 61,31\%.

\section{DAFTAR PUSTAKA}

Aksit, F., Niemi, H., \& Nevgi, A. (2016). Why is active learning so difficult to implement: The Turkish case. Australian Journal of Teacher Education, 41(4), 94-109. https://doi.org/10.14221/ajte.2016v41n 4.6

Balım, A. G. (2009). The Effects of Discovery Learning on Students ' Success and Inquiry Learning Skills. Eurasian Journal of Educational Research, (35), 1-20. https://doi.org/10.6084/m9.figshare.34 37033

Cohen, M. T. (2008). The effect of direct instruction versus discovery learning on the understanding of science lessons by second grade students. NERA Conference Proceedings, Paper 30, 2-37.
Eka Andriani, Sumarmi, I. K. A. (2016). Peningkatan Kompetensi Pedagogik Guru, 1, 2106-2112.

Hamid, M. A. (2016). Pengembangan Instrumen Penilaian Hasil Belajar Siswa berbasis TIK pada Pembelajaran Dasar Listrik Elektronika. Jurnal Ilmiah Pendidikan Teknik Elektro, 1(1), 37-46. Retrieved from jurnal.untirta.ac.id/index.php/VOLT

Helliar, A. T., \& Harrison, T. G. (2011). the Role of School Technicians in Promoting Science Through Practical Work, 4(2).

Hermawan, I. K. D. (2014). Analisis Sumber Daya Manusia Pendidikan Tinggi. Jurnal Pendidikan Dan Kebudayaan, 17(4), $404=418$.

Ismail. (2010). Ismail, KINERJA DAN KOMPETENSI GURU DALAM PEMBELAJARAN Oleh: Muh. Ilyas Ismail * ABSTRAK:, 13(1), 44-63.

Joy, A. (2014). Impact of discovery-based learning method on senior secondary school physics. IOSR Journal of Research \& Method in Education, 4(3), 32-36. Retrieved from www.iosrjournals.org

Kapucu, S. (2016). Identification of the Physics Subjects That Are Liked / Disliked and Why These Subjects Are Liked / Disliked By Student, 12(4), 827-843.

Khabibah, E. N., Masykuri, M., \& Maridi, M. (2017). The Effectiveness of Module Based on Discovery Learning to Increase Generic Science Skills. Journal of Education and Learning (EduLearn), 11(2), 146. https://doi.org/10.11591/edulearn.v11i 2.6076

Martaida, T., Bukit, N., \& Ginting, E. M. (2017). The Effect of Discovery Learning Model on Student's Critical Thinking and Cognitive Ability in Junior High School, 7(6), 1-8. https://doi.org/10.9790/73880706010108 
Mirzagitova, A. L., \& Akhmetov, L. G. (2015). Selfdevelopment of pedagogical competence of future teacher. International Education Studies, $\quad 8(3)$, 114-121. https://doi.org/10.5539/ies.v8n3p114

Mupa, P., \& Chinooneka, T. I. (2015). Factors Contributing to Ineffective Teaching and Learning in Primary Schools: Why Are Schools in Decadence? Journal of Education and Practice, 6(19), 125-132. Retrieved from http://search.ebscohost.com/login.aspx? direct $=$ true $\& \mathrm{db}=$ eric $\& A N=E J 1079543 \&$ si te=ehost-live

Nasrudin, D. (2012). MODEL SIKLUS BELAJAR 5E BERBASIS KONFLIK KOGNITIF PADA MATERI SUHU DAN KALOR UNTUK MENINGKATKAN PENGUASAAN KONSEP DAN KETERAMPILAN BERPIKIR KREATIF SISWA SMA (Doctoral dissertation, Universitas Pendidikan Indonesia).

Pangaribowo, D. ., Keliat, N. ., Sastrodihardjo, S., \& Hutangoal, D. . (2017). Penerapan Model Pembelajaran Discovery Learning dan Permainan Smart Case untuk Meningkatkan Hasil Belajar Siswa Kelas VII C SMP Kristen 2 Salatiga. Bioedukasi, 10(1), 47-57.

Rochman, C. (2015). Analisis dan kontribusi kemampuan konsep dasar fisika, literasi kurikulum pembelajaran dan psikologi pembelajaran terhadap kemampuan penyusunan Lembar Kegiatan Peserta Didik (LKPD) mahasiswa pendidikan fisika. Prosiding Simposium Nasional Inovasi Dan Pembelajaran Sains (Snips), 15.

Rosdiana., Boleng, T. D., \& Susilo. (2017). Pengaruh penggunaan Model Discovery Learning Terhadap Hasil Belajar Siswa. Jurnal Pendidikan, 2(8), 1060-1064.
Sijaya, I., Yani, A., \& Ma'ruf. (2015). Peranan Media Presentase Interaktif Terhadap Hasil Belajar Fisika Pada Peserta Didik Kelas X SMA Islam Darussalam. Jurnal Pendidikan Fisika, 4, 328-341. Retrieved from http://journal.unismuh.ac.id/index.php/j pf/article/download/331/305

Suphi, N., \& Yaratan, H. (2016). Effects of discovery learning and student assessment on academic success. Turkish Online Journal of Educational Technology, 2016(NovemberSpecialIssue), 829-835.

Wingrave, C., Norton, J., Ross, C., Ochoa, N., Veazanchin, S., Charbonneau, E., \& LaViola, J. (2012). Inspiring creative constructivist play. Proceedings of the 2012 ACM Annual Conference Extended Abstracts on Human Factors in Computing Systems Extended Abstracts - CHI EA '12, $3(3)$,

2339. https://doi.org/10.1145/2212776.2223 799 